\title{
Evaluation of Antibacterial Activities of Medicinal Plants
}

\author{
NareshMaharjan', AnjanaSingh', MangalaD. Manandhar ${ }^{2}$ \\ Shaila Basnyat ${ }^{1}$ Binod Lekhak $^{1}$ and Surya K. Kalauni ${ }^{2}$ \\ ${ }^{1}$ Central Department of Microbiology \\ Tribhuvan University, Kirtipur, Kathmandu \\ ${ }^{2}$ Central Department of Chemistry \\ Tribhuvan University, Kirtipur, Kathmandu \\ e-mail: naresh_kirtipur@yahoo.com
}

\begin{abstract}
Plant and plant products are used as medicine from the beginning of human civilization. This study compares the antibacterial activity of crude hexane, ethylacetate and methanol extracts of nine different medicinal plants used in traditional Nepalese medicine, tested against 10 species of bacteria: Staphylococcus aureus (ATCC 25923), Escherichia coli (ATCC 25922), Klebsiella pneumoniae (ATCC 20063), Klebsiella oxytoca, Proteus mirabilis (ATCC 49132), Proteus vulgaris, Pseudomonas aeruginosa (ATCC 27853), Salmonella typhi, Salmonella paratyphi and Shigella dysenteriae by agar well diffusion method. The selected parts of these medicinal plants namely Acorus calamus (Rhizome), Aegle marmelos (Fruit), Asparagus racemosus (Tuberous root), Mimosa pudica (Root), Terminalia bellirica (Fruit), Terminalia chebula (Fruit), Tinospora cordifolia (Stem), Woodfordia fruticosa (Flower) and Holarrhena antidysenterica (Seed) were taken for study.The result showed that out of nine tested plants, four plant extracts (44\%) showed activity against at least five or more tested bacteria and five plant extracts (56\%) were active against three or less than three bacteria. None of the tested plant extracts was active against all the tested bacteria. A. racemosus was the least effective against bacterial species. $S$. aureus was the most susceptible bacteria being sensitive to 18 extracts from 9 medicinal plants. P. vulgaris was the most resistant bacteria being resistant to all selective plants. The MBC value ranges from $3.12 \mathrm{mg} / \mathrm{ml}$ to $>50 \mathrm{mg} / \mathrm{ml}$. Lowest MBC was shown by ethylacetate extract of $T$. bellirica against $E$. coli and ethylacetate extract of $W$. fruticosa against $S$. dysenteriae. Largest ZOI (31 $\mathrm{mm}$ ) was produced by ethylacetate extract of $T$. bellirica.
\end{abstract}

Key words: antibacterial activity, medicinal plants, plant extracts

\section{Introduction}

Plants and plant products have been a source of food and medicines from the dawn of human civilization. The earliest mention of medicinal use of plants on Indian subcontinent has been found in the Rigveda which was written between 4500-1600 BC (HMG 1993). Nepal Himalaya, globally significant and biologically diverse ecosystem is rich in varieties of medicinal plants. Among the 7000 species of medicinal plants recognized all over the world, more than 900 types of precious medicinal plants are said to be found in Nepal (Manandhar 2000). In Nepal, about 75-80\% of the rural populations use these traditional remedies (HMG 2007). The knowledge about the use of medicinal plants is deeply rooted in the traditional and culture of Nepalese people living in rural areas (Rijal 1994).
Infectious diseases caused by baceria, fungi, viruses and parasites are still a major threat to public health, despite the tremenodous progress in human medicine. The clinical efficacy of many existing antibiotics is being threatened by the emergence of multi-drug resistant pathogens (Kumar et al. 2002). Bacterial and fungal pathogens have evolved numerous defense mechanisms against anti-microbial and resistance to old and newly produced drugs is on rise. This increase has been attributed to indiscriminate use of broadspectrum antibiotics and immunosuppressive agent (Kokoska et al.2002). In addition, in developing countries, synthetic drugs are not only expensive and inadequate for the treatment of diseases but also often with adulterations and side effects. Therefore, there is 
need to search new infection- fighting strategies to control microbial infections (Sieradzki et al. 1999). Innumerable biologically active compounds are found in plants that posses antimicrobial properties which represent a vast untapped source of medicines (Branter \& Grein 1994). These active compounds are found in various parts such as root, shoot, bark, fruit and sometime throughout whole plant.

The aim of this study was to evaluate the antimicrobial activity of some medicinal plants selected on the basis of their common use in Ayurveda and among the different ethnic groups of Nepal for common disorder. Therefore, extracts of the following 9 medicinal plants were tested for their potential activity against microbial pathogens: Acorus calamus, Aegle marmelos, Woodfordia fruticosa, Tinospora cordifolia, Asparagus racemosus, Terminalia chebula, Terminalia bellirica, Mimosa pudica and Holarrhena antidysenterica.

\section{Methodology}

This study was conducted from June 2007 to July 2008, partly in the Central Department of Microbiology, T.U and partly in the Central Department of Chemistry, T.U., Kirtipur. The extraction part of the study was carried out at the Central Department of Chemistry and antibacterial activity of the plants was carried out in laboratory of Central Department of Microbiology.

\section{Collection of medicinal plants}

The selected nine medicinal plants were collected from different parts of Nepal. They were identified according to the description given on different books viz: Flora of Kathmandu valley (1986), Flora of British India (1992) and other pertinent taxonomic literature. Collected samples were then chopped into small fragments and dried. Then samples were ground to obtain fine powder.

Table 1. List of medicinal plants used in the evaluation of antimicrobial activities

\begin{tabular}{|c|c|c|c|c|}
\hline Medicinal plants & Family & Part(s) used & $\begin{array}{c}\text { Place of } \\
\text { collection }\end{array}$ & Traditional uses \\
\hline Acorus calamus & Araceae & Rhizome & Kirtipur & $\begin{array}{l}\text { Remitted fevers, cough, bronchitis, sore throat, } \\
\text { diuretic, epilepsy, helminthiasis (Baral \& Kurmi } \\
\text { 2006, Rajbhandari et al. 1995) }\end{array}$ \\
\hline Aegle marmelos & Rutaceae & Fruit & Surkhet & $\begin{array}{l}\text { Diarrhea, dysentery, laxative, digestive (Baral \& } \\
\text { kurmi 2006) }\end{array}$ \\
\hline Asparagus racemosus & Liliaceae & $\begin{array}{l}\text { Tuberous } \\
\text { root }\end{array}$ & Chitwan & $\begin{array}{l}\text { Diarrhea, dysentery, leucorrhoea, uterine disorder, } \\
\text { ulcerated tongue, jaundice, fever, galactogogue, } \\
\text { diuretic (Joshi 2006) }\end{array}$ \\
\hline Mimosa pudica & Leguminosae & Root & Nawalparasi & $\begin{array}{l}\text { Diarrhea, dysentery, leucorrhea, hydrocele, piles, } \\
\text { fistula, wound infection (Joshi 2006) }\end{array}$ \\
\hline Terminalia bellirica & Combretaceae & Fruit & Dhankuta & $\begin{array}{l}\text { Diarrhea, leprosy, fever, headache, dyspepsia, } \\
\text { biliousness, dropsy, laxative, tonic (HMG/N 1993) }\end{array}$ \\
\hline Terminalia chebula & Combretaceae & Fruit & Dhankuta & $\begin{array}{l}\text { Cough, bronchitis, ulcers, wound infection, } \\
\text { swelling, skin and eye diseases, chronic and } \\
\text { recurrent fever, diuretic, digestive, ulceration of } \\
\text { gum, laxative (Joshi 2006, HMG/N 1993) }\end{array}$ \\
\hline Tinospora cordifolia & Menispermaceae & Stem & Chitwan & $\begin{array}{l}\text { Fever, skin diseases, leprosy, splenopathy, , } \\
\text { jaundice, cough, asthma, uropathy, gonorrhea, } \\
\text { gout, tonic, expectorant, immunomodulator ( Baral } \\
\text { \& Kurmi 2006, Joshi 2006) }\end{array}$ \\
\hline Woodfordia fruticosa & Lythraceae & Flower & Kirtipur & $\begin{array}{l}\text { Antibacterial, diarrhea, dysentery, helminthiasis, } \\
\text { leprosy , ulcers, hepatopathy, haemorrhoids, skin } \\
\text { diseases, foul ulcers, uterine sedative ( Baral \& } \\
\text { Kurmi } 2002 \text {, Rajbhandari et al. 1995) }\end{array}$ \\
\hline $\begin{array}{c}\text { Holarrhena } \\
\text { antidysenterica }\end{array}$ & Apocynaceae & Seed & Kavre & $\begin{array}{l}\text { Diarrhea , dysentery, eczema, piles, leprosy, } \\
\text { helminthiasis, febrifuge, carminative, astringent } \\
\text { (IUCN 2000) }\end{array}$ \\
\hline
\end{tabular}

\section{Extraction of plant materials}

Finely powdered plant parts were subjected to continuous extraction from three different solvents viz hexane, ethylacetate and methanol in the order of increasing polarity, by using soxhlet apparatus to obtain crude extract viz hexane extract, ethylacetate extract and methanol extract respectively. After complete extraction, the solvent will be totally removed 
by using rotary evaporator and these extracts were separately assayed for their antibacterial activity.

\section{Prepation of stock/working solution}

Stock solution $(100 \mathrm{mg} / \mathrm{ml})$ of each crude extract was made by dissolving $1 \mathrm{~g}$ of extract in $10 \mathrm{ml}$ of dimethyl sulphoxide (DMSO) in clean and capped test tubes, which were sealed and stored in refrigerator $\left(2-8^{\circ} \mathrm{C}\right)$ until use.

\section{Collection of standard culture}

The hexane, ethylacetate and methanol extracts of medicinal plants were screened against a total of 10 bacterial strains: Staphylococcus aureus (ATCC
25923), Escherichia coli (ATCC 25922), Klebsiella pneumoniae (ATCC 20063), Klebsiella oxytoca, Proteus mirabilis (ATCC 49132), Proteus vulgaris, Pseudomonas aeruginosa (ATCC 27853), Salmonella typhi, Salmonella paratyphi and Shigella dysenteriae.

\section{Antibacterial activity assay}

The antibacterial activity of crude extract of medicinal plants was screened against the test organism by agar well diffusion method as given by Dingle et al. (1953). The bacterial isolates were first grown in a nutrient broth and standardized to $0.5 \mathrm{Mc}$ Farland $\left(10^{6} \mathrm{CFU} /\right.$ $\mathrm{ml}$ ). Inoculums containing $10^{6} \mathrm{CFU} / \mathrm{ml}$ of bacteria were

Table 2. Antibacterial activities of extracts of medicinal plants against tested bacteria

\begin{tabular}{|c|c|c|c|c|c|c|c|c|c|c|c|c|}
\hline \multirow{2}{*}{$\begin{array}{l}\text { S. } \\
\text { No. }\end{array}$} & \multirow[t]{2}{*}{ Plants } & \multirow[b]{2}{*}{ 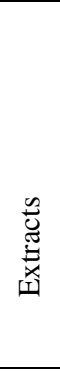 } & \multicolumn{10}{|c|}{ ZOI (mm) shown by plants against tested bacteria } \\
\hline & & & 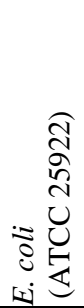 & 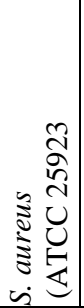 & 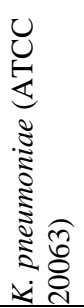 & 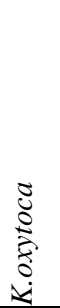 & $\begin{array}{l}\tilde{\frac{\pi}{2}} \\
\vec{\lambda} \\
\dot{s}\end{array}$ & 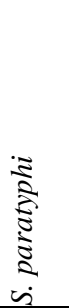 & 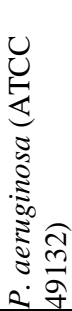 & 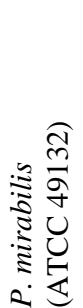 & 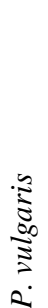 & 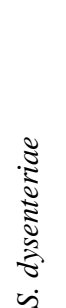 \\
\hline \multirow[t]{3}{*}{1.} & A.calamus & $\mathrm{He}$ & - & 13 & - & - & - & - & - & - & - & - \\
\hline & & Ea & 13 & 18 & - & - & - & - & - & - & - & 17 \\
\hline & & $\mathrm{Me}$ & - & 12 & - & - & - & - & - & - & - & - \\
\hline \multirow[t]{3}{*}{2} & H. antidysentrica & $\mathrm{He}$ & 11 & - & - & - & - & & - & - & - & - \\
\hline & & Ea & - & - & - & - & - & - & - & 11 & - & 17 \\
\hline & & $\mathrm{Me}$ & - & 12 & - & 10 & - & - & 11 & - & - & - \\
\hline \multirow[t]{3}{*}{3} & W. fructicosa & $\mathrm{He}$ & - & - & - & - & - & - & - & - & - & 14 \\
\hline & & Ea & 26 & 20 & - & - & 15 & 14 & - & - & - & 26 \\
\hline & & $\mathrm{Me}$ & - & 16 & 12 & - & - & - & - & - & - & 23 \\
\hline \multirow[t]{3}{*}{4} & T. bellerica & $\mathrm{He}$ & - & - & - & - & - & - & - & - & - & - \\
\hline & & $\mathrm{Ea}$ & 31 & 18 & - & 13 & 18 & - & 15 & - & - & 17 \\
\hline & & $\mathrm{Me}$ & 21 & 19 & - & - & - & - & - & - & - & 19 \\
\hline \multirow[t]{3}{*}{5} & T. chebula & $\mathrm{He}$ & - & 11 & - & - & - & - & - & - & - & - \\
\hline & & $\mathrm{Ea}$ & 13 & 19 & - & 12 & - & 18 & - & - & - & 21 \\
\hline & & $\mathrm{Me}$ & - & 21 & - & - & - & - & - & - & - & 22 \\
\hline \multirow[t]{3}{*}{6} & T. cordifolia & $\mathrm{He}$ & - & - & - & - & - & - & 13 & - & - & - \\
\hline & & $\mathrm{Ea}$ & - & - & - & - & - & - & - & - & - & - \\
\hline & & $\mathrm{Me}$ & - & - & - & 14 & - & - & - & 13 & - & - \\
\hline \multirow[t]{3}{*}{7} & M. pudica & $\mathrm{He}$ & - & 10 & - & - & - & - & - & - & - & - \\
\hline & & $\mathrm{Ea}$ & - & 19 & - & - & - & - & - & - & - & - \\
\hline & & $\mathrm{Me}$ & - & 21 & - & 16 & - & 17 & - & - & - & - \\
\hline \multirow[t]{3}{*}{8} & A. racemosus & $\mathrm{He}$ & - & - & - & - & - & - & - & - & - & - \\
\hline & & $\mathrm{Ea}$ & - & 13 & - & - & - & - & - & - & - & - \\
\hline & & $\mathrm{Me}$ & - & - & - & - & - & - & - & 13 & - & - \\
\hline \multirow[t]{3}{*}{9} & A. marmelos & $\mathrm{He}$ & - & 13 & - & - & - & - & - & - & - & - \\
\hline & & Ea & - & 16 & 12 & - & - & - & - & - & - & 18 \\
\hline & & $\mathrm{Me}$ & - & 12 & 12 & - & - & - & & - & - & 20 \\
\hline
\end{tabular}

Note: $\mathrm{He}=$ Hexane, Ea = Ethylacetate, $\mathrm{Me}=$ Methanol 
spread on the solid Muller-Hinton Agar (MHA) plates with a sterile cotton swabs moistened with the bacterial suspension. Wells were made in plates using sterile cork borer (8 mm diameter). The working suspension/ solution $(100 \mu \mathrm{l})$ of different medicinal plant extracts $(100 \mathrm{mg} / \mathrm{ml})$ and same volume of DMSO as a control were filled in the wells with the help of micropipettes. The plates were left for sometime so that the extracts diffused into media and they were incubated at $37^{\circ} \mathrm{C}$ for 24 hours. After overnight incubation, the plates were observed for zone of inhibition (ZOI) and diameter of ZOI were scaled and were recorded. The triplicate assay was performed in case of the presence of Zone of inhibition. Then the mean of ZOI was recorded.

\section{Determination of minimum bactericidal concentration (MBC)}

The crude extracts of different fractions of medicinal plants, which showed antibacterial activity were then subjected to two fold serial dilution method as described by Baron et al. (1994) to determine minimum bactericidal concentration (MBC).

\section{Results and Discussion}

In this study, 27 extracts obtained by continuous extraction from 9 different plants using hexane, ethylacetate and methanol solvents in the order of increasing polarity were studied for their antimicrobial

Table 3. Minimum bactericidal concentration (MBC) shown by plants against tested bacteria

\begin{tabular}{|c|c|c|c|c|c|c|c|c|c|c|c|c|}
\hline \multirow{2}{*}{$\begin{array}{l}\text { S. } \\
\text { No. }\end{array}$} & \multirow[t]{2}{*}{ Plants } & & \multicolumn{10}{|c|}{ MBC (mg/ml) shown by plants against tested bacteria } \\
\hline & & 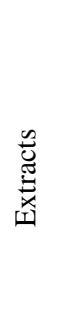 & 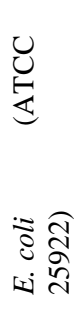 & 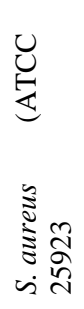 & 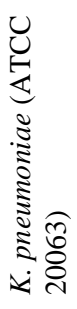 & 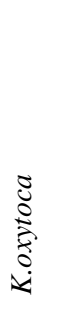 & $\begin{array}{l}\stackrel{\vec{a}}{\frac{a}{2}} \\
\text { vis }\end{array}$ & 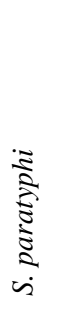 & 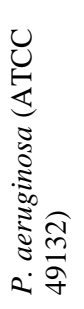 & 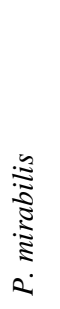 & 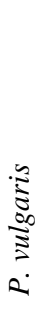 & 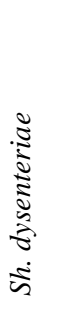 \\
\hline \multirow[t]{3}{*}{1.} & A.calamus & $\mathrm{He}$ & - & 25 & - & - & - & - & - & - & - & - \\
\hline & & $\mathrm{Ea}$ & 50 & 12.5 & - & - & - & - & - & - & - & 25 \\
\hline & & $\mathrm{Me}$ & - & 25 & - & - & - & - & - & - & - & - \\
\hline \multirow[t]{3}{*}{2} & $H$. & $\mathrm{He}$ & 25 & - & - & - & - & & - & - & - & - \\
\hline & antidysentrica & Ea & - & - & - & - & - & - & - & 50 & - & 6.25 \\
\hline & & $\mathrm{Me}$ & - & 50 & - & 25 & - & - & 25 & - & - & - \\
\hline \multirow[t]{3}{*}{3} & $W$. & $\mathrm{He}$ & - & - & - & - & - & - & - & - & - & 50 \\
\hline & fructicosa & $\mathrm{Ea}$ & 12.5 & 12.5 & - & - & 25 & 25 & - & - & - & 3.12 \\
\hline & & $\mathrm{Me}$ & - & 25 & 50 & - & - & - & - & - & - & 6.25 \\
\hline \multirow[t]{3}{*}{4} & $T$. & $\mathrm{He}$ & _- & - & - & - & - & _- & - & - & - & - \\
\hline & bellerica & $\mathrm{Ea}$ & 3.12 & 6.25 & - & 25 & 6.25 & - & 50 & - & - & 25 \\
\hline & & $\mathrm{Me}$ & 12.5 & 12.5 & - & - & - & - & - & - & - & 12.5 \\
\hline \multirow[t]{3}{*}{5} & $T$. & $\mathrm{He}$ & - & $>50$ & - & - & - & - & - & - & - & - \\
\hline & chebula & Ea & 25 & 12.5 & - & 50 & - & 12.5 & - & - & - & 12.5 \\
\hline & & $\mathrm{Me}$ & - & 6.25 & - & - & - & - & - & - & - & 12.5 \\
\hline \multirow[t]{3}{*}{6} & $T$. & $\mathrm{He}$ & - & - & - & - & - & - & 50 & - & - & - \\
\hline & cordifolia & Ea & - & - & - & - & - & - & - & - & - & - \\
\hline & & $\mathrm{Me}$ & - & - & - & 25 & - & - & - & 25 & - & - \\
\hline \multirow[t]{3}{*}{7} & M. & $\mathrm{He}$ & - & 50 & - & - & - & - & - & - & - & - \\
\hline & pudica & Ea & - & 25 & - & - & - & - & - & - & - & - \\
\hline & & $\mathrm{Me}$ & - & 25 & - & 25 & - & 50 & - & - & - & - \\
\hline \multirow[t]{3}{*}{8} & A. & $\mathrm{He}$ & - & - & - & - & - & - & - & - & - & - \\
\hline & racemosus & Ea & - & 50 & - & - & - & - & - & - & - & - \\
\hline & & $\mathrm{Me}$ & - & - & - & - & - & - & - & 50 & - & - \\
\hline \multirow[t]{3}{*}{9} & A. & $\mathrm{He}$ & - & 25 & - & - & - & - & - & - & - & - \\
\hline & marmelos & $\mathrm{Ea}$ & - & 25 & 50 & - & - & - & - & - & - & 3.12 \\
\hline & & $\mathrm{Me}$ & - & 25 & 50 & - & - & - & & - & - & 6.25 \\
\hline
\end{tabular}

Note: $\mathrm{He}=$ Hexane, Ea = Ethylacetate, $\mathrm{Me}=$ Methanol 
literature and folklore for diseases like cough, fever, wounds, diarrhea, dysentery, etc.

The antibacterial activities of hexane, ethylacetate and methanol extracts of nine selected plants showed that four plant extracts (44\%) showed activity against at least five or more tested bacteria and five plant extracts (56\%) were active against three or less than three tested bacteria. None of the tested plant extracts was active against all the tested bacteria. $H$. antidysenterica, $T$. bellerica and $W$. fructicosa showed relatively broad spectrum antibacterial activity (inhibited 6 out of 10 bacterial species) while $A$. racemosus showed least antibacterial activity (inhibited only 2 species). The highest ZOI (31 mm) was shown by ethylacetate fraction of T. bellirica against E. coli (Table 2).

The results showed that $A$. calamus inhibited 3 bacterial species viz. E. coli, $S$. dysenteriae and $S$. aureus. According to Souwalak et al. (2005) A. calamus was effective against $S$. aureus which supported with the result of this study. A. racemosus inhibited only $P$. mirabilis and $S$. aureus. This is supported by the result obtained by Baidya (2001). $H$. antidysenterica showed relatively broad spectrum activity, which inhibited 6 bacterial species. Baidya (2001) showed similar results with ethanol extracts. Methanol fraction of $M$. pudica inhibited S. aureus, $K$. oxytoca and S. paratyphi, which didnot support the study of Bajracharya (2007), where none of the tested bacteria was inhibited by $M$. pudica. Ethylacetate extracts of $T$. bellirica inhibited the growth of 6 bacterial species, methanol extract inhibited 3 bacterial species while hexane fraction did not inhibit any tested bacterial species, which was similar to the result showed by Ahmad (1998). The result showed that the active compounds might be polar compounds. Table 2 further showed that T. chebula inhibited 5 tested bacterial species, which further showed that methanol and ethylacetate extracts showed more inhibitory effect than hexane extracts. $W$. fructicosa was effective against 6 tested bacteria and the most effective extracts were found to be ethylacetate extracts against $E$. coli and $S$. dysenteriae. A. marmelos inhibited 3 tested bacterial species and all the three extracts showed antibacterial activity with $S$. aureus.

Further study showed that $S$. aureus was the most susceptible bacteria being sensitive to 18 extracts from 8 medicinal plants. Among tested Gram negative bacteria, $S$. dysenteriae was the most susceptible bacteria being sensitive to 11 extracts from 6 medicinal plants and $P$. vulagaris was the most resistant bacteria to all the selected plants. Further results showed that hexane extracts from 7 plants, ethylacetate extracts from 8 plants and methanol extracts from all plants showed antimicrobial activity against the tested bacterial species.

Table 3 showed the MBC of different effective extracts. The most bactericidal and lowest MBC of $3.12 \mathrm{mg} / \mathrm{ml}$ was shown by ethylacetate extract of $T$. bellirica against $E$. coli and ethylacetate extract of $W$. fructicosa against $S$. dysenteriae. Most of the MBC value of other plant extracts were in the ranges of 6.25 to 25 $\mathrm{mg} / \mathrm{ml}$. Least potent i.e. highest MBC value (>50 mg/ $\mathrm{ml}$ ) was shown by hexane extract of $T$. chebula against S. aureus.

The extracts from medicinal plants showing large ZOI and small MBC value, may contain those compounds, which are able to inhibit or kill the microbial populations of tested bacteria.

From this study it can be concluded that the selected medicinal plants had antibacterial activity against common pathogenic bacterial species.

\section{Acknowledgements}

The authors would like to express their deep thanks to all the staff of the Central Department of Microbiology and Chemistry,Tribhuvan University, Kirtipur, for their kind help in this research.

\section{References}

Ahmad, I. and A.Z. Beg. 2001. Antimicrobial and phytochemical studies on 45 Indian medicinal plants against multi-drug resistant human pathogens. Journal of Ethnopharmacology 74:113-123.

Alade, P.I. and O.N. Irobe. 1993. Antibacterial activities of crude extracts of Acalypha wilkesinan from Manna Nigeria. Journal of Ethnopharmacology 39: 235-236.

Ananthanarayan, R. and C.K.J. Panikar. 2001. Textbook of Microbiology. $6^{\text {th }}$ Edition. Reprint, Orient Longman Pvt. Ltd. pp. 250-298.

Baidya, M.R. 2001. Screening and evaluation of in-vitro antimicrobial activity of some medicinal plants of Nepal. M.Sc. thesis Central Department of Microbiology, Tribhuvan University, Kiritipur, Kathmandu, Nepal.

Bajaracharya, A.M. 2007. Study of drinking water quality of Kathmandu metropolitian area and evaluation of 
Nepal Journal of Science and Technology Vol. 13, No. 2 (2012) 209-214

antibacterial property of some medicinal plants against isolated enteric bacteria. M.Sc. Thesis. Thesis Central Department of Microbiology, Tribhuvan University, Kiritipur, Kathmandu, Nepal.

Baral, S.R. and P.R. Kurmi. 2006. A compendium of medicinal plants in Nepal. IUCN. The World Conservation Union. pp. 52-392.

Baron, E.J., L.R. Peterson. and S.M. Finegold. 1994. Bailey and Scotts diagnostic Microbiology, $9^{\text {th }}$ Edition. Mosby year Book, Inc. USA. pp. 166-177.

Branter, A. and E. Grein. 1994. Antibacterial activity of plant extracts used externally in traditional medicine. Journal of Ethnopharmacology 44: 35-40.

Dingle, J., W.W. Reed and G.L. Solomons. 1953. The enzymatic degradation of pectin and other polysaccharides II. Application of the cup assay method to the estimation of enzyme. Journal of Science, Food and Agriculture 4:149-153.

HMG/G. 1986. Standards of ayurvedic crude drugs. Ministry of Forest, Department of Medicinal Plants. Kathmandu, Nepal. pp. 25-160.

HMG/G. 1993. Medicinal plants of Nepal. Ministry of Forest and Soil Conservation, Department of Medicinal Plants, Kathmandu, Nepal. pp. 72-150.

HMG/G. 2002. Forest and vegetation types of Nepal tree improvement and silviculture component. Department of Forest and Soil Conservation, Kathmandu, Nepal. pp. 170.

IUCN. 2000. National register of medicinal plants. IUCN/ Nepal 13:200-202.

Iwu, M.M., A.R. Duncan and C.O. Okunji. 1999. Prospective on new crops and new uses. In: New Antimicrobial of Plants Origin (Ed.J.Janick). ASHA, Press Alexandrial, U.S.A.

Joshi, S.G. 2006. Medicinal plants. Oxford and IBH Publishing Co. PVT. Ltd. New Delhi, India. pp. 52-246.
Kokoska, L., Z. Polesny, V. Rada, A. Nepovim. and T. Vanek. 2002. Screening of some Siberian medicinal plants for antimicrobial activity. Journal of Ethnopharmacology 82: 51-53.

Kumar, V., T. Shah, G.B. Shah. and N.S. Parrnar. 2002. Antibacterial activity of Bergenia ciliate rhizomes. Indian Journal of Natural Products 18: 22-25.

Machado, T.B., A.V. Pinto, C.R. Leal, M.G. Silva, A.C.F. Amaral, R.M. Kuster. and K.R. Netto. 2003. In vitro activity of Brazilian medicinal plants, naturally occurring naphthoquinones and their analogues, against methicilin-resistant Staphylococcus aureus. International Journal of Microbiology 21: 279-284.

Manandhar, N.P. 2000. Plants and people of Nepal. Timber Press, USA.

Rajbhandari, T.K., N.R. Joshi, T. Shrestha, S.K.G. Joshi and B. Acharya. 1995. Medicinal plants of Nepal for Ayurvedic drugs. HMG/N, Natural Products Development Division, Thapathali, Kathmandu, Nepal.

Rijal, K. 1994. Preliminary study on some medicinal plants and essential oils for their antimicrobial activities. In: proceedings of national conference on science and technology. RONAST, Kathmandu, Nepal. pp. 390-393.

Sieradzki, K., S.W. Wu and A. Tomasz. 1999. Inactivation of the methicillin resistance gene mec A in vancomycin-resistant Staphylococcus aureus. Journal of Microbiology Drug Resistance 5(4): 253257.

Souwalak, P., P. Nongyao, R. Vatcharin and O. Metto. 2005. Antimicrobial activities of the crude methanol extracts of Acorus calamus Linn. Songklanakarin. Journal of Science and Technology 27(2): 517-523.

WHO. 1991. Basic laboratory procedure in clinical bacteriology. World Health Organization, Geneva. 